\title{
Análise do perfil das habilidades pragmáticas em crianças pequenas normais $* * * *$
}

\author{
Analysis of the pragmatic abilities profile in normal preschool \\ children
}

\author{
Simone Rocha de Vasconcellos Hage* \\ Marta Maria Resegue** \\ Daniele Cristina Sedano de Viveiros*** \\ Elaine Florentino Pacheco***
}

*Fonoaudióloga. Pós-Doutoranda em Psicologia da Linguagem pela Universidade de Navarra (Espanha). Professora Doutora do Departamento de Fonoaudiologia da Faculdade de Odontologia de Bauru da Universidade de São Paulo. Endereço para correspondência: Al. Dr. Octávio Pinheiro Brisolla, 9-75 - Bauru - SP CEP 17012-901 (simonehage@uol.com.br).

**Fonoaudióloga. Mestranda do Programa de Pós-Graduação em Fonoaudiologia da Faculdade de Odontologia de Bauru - Universidade de São Paulo.

***Fonoaudióloga da Fonotek Assessoria Fonoaudiológica Uberlândia (MG).

****Trabalho Realizado na Universidade de São Paulo - Campus de Bauru.

Artigo de Pesquisa

Artigo Submetido a Avaliação por Pares

Conflito de Interesse: não

Recebido em 17.03.2006.

Revisado em 18.05.2006; 14.09.2006; 10.03.07.

Aceito para Publicação em 10.03.07.

\section{Abstract}

Background: pragmatic abilities in children. Aim: to analyze the pragmatic abilities profile in normal preschool children and to verify if significant differences exist regarding the children's different socioeconomic levels. Method: participants of this study were 30 children, with ages between 36 and 47 months, who attended public and private elementary schools - low and medium/high socioeconomic levels respectively. A thirty minute semi-structured conversation between each child and the evaluator was recorded in VHS. For the analysis of the pragmatic abilities profile 20 minutes of each conversation was transcribed. Results: there is a prevalence of verbal over non-verbal and unintelligible utterances; simple over expansive utterances; coherent over incoherent utterances. There was a low occurrence of utterances used to start a conversation. Regarding the use of communicative functions, the informative function prevailed, even though all the others (instrumental, heuristic, naming, narrative, negative, interactive) were used by all of the children. Comparing the performance of children who attended public schools with that of children who attended private schools, statistically significant differences were observed in the number of simple and expansive verbal utterances, and in the use of the narrative function, indicating a better performance of children from private institutions. Conclusion: the analysis of the children's conversational abilities profile revealed that they respond/maintain the conversation instead of initiating it; their utterances are verbal, mostly coherent and simple. Regarding the communicative functions, the most prevalent was the informative function. Sociolinguistic aspects can interfere in the pragmatic abilities of children of different socioeconomic level.

Key Words: Assessment Language; Developmental Language; Pragmatic; Conversational Skills; Communicative Functions.

\section{Resumo}

Tema: habilidades pragmáticas em crianças. Objetivo: analisar o perfil das habilidades pragmáticas em crianças pequenas, sem alterações de linguagem e verificar se há diferenças significantes nestas habilidades, considerando o nível sócio-econômico destas crianças. Método: participaram do estudo 30 crianças, entre 36 e 47 meses, pertencentes a escolas de educação infantil pública e privada, cuja população que freqüenta é de nível sócio-econômico baixo e médio/alto, respectivamente. Foi registrado, em fita VHS, 30 minutos de conversação semi-estruturada entre a criança e o avaliador, sendo transcritos e analisados 20 minutos. Resultados: há maior ocorrência de turnos verbais em relação aos não verbais e ininteligíveis; turnos simples em relação aos expansivos, coerentes em relação aos incoerentes. Houve baixa ocorrência de turnos de iniciação de conversação. $\mathrm{Na}$ análise das funções comunicativas predominou a informativa, muito embora todas as outras (instrumental, heurística, nomeação, narrativa, protesto, interativa) tenham sido utilizadas por todas as crianças. Comparando-se o desempenho das crianças das instituições públicas e privadas, constataram-se diferenças estatisticamente significantes para a ocorrência dos turnos verbais, simples e expansivos, e uso da função narrativa, sendo que a maior ocorrência se deu nas amostras de linguagem das crianças da instituição privada. Conclusão: a análise do perfil das habilidades conversacionais das crianças revelou que elas mais respondem/mantém do que iniciam a conversação, todavia, seus turnos são verbais, em sua maioria, coerentes e simples. Quanto à funcionalidade, a função predominante é a informativa. Aspectos sóciolingúisticos podem interferir nas habilidades pragmáticas de crianças de diferentes níveis sócio-econômicos.

Palavras-Chave: Avaliação de Linguagem; Desenvolvimento da Linguagem; Pragmática; Habilidades Conversacionais; Funções Comunicativas. 


\section{Introduction}

Studies about the development of pragmatic abilities are recent if compared to studies about phonological, semantic or syntactic development. One of the main contributions of the pragmatic perspective was to include pre-verbal communication in the study of children's language. It is during the pre-linguistic period that starts the use of language to interact with people and to determine the functional basis of communication.

The interest in studying the intentional use of language, that is, pragmatics, began in the end of the 1970 decade, with the functionalist perspective of language, opposed to the structuralism that was dominant in that period (Acosta et al. 2003).

In the studies about infantile language the pragmatic theories focus basically in two aspects: communicative functions and conversational abilities. Communicative functions are abstract units that reflect the speaker's communicative intent. They involve motivation, aims and objectives that one wishes to achieve by communicating with other. Conversational abilities refer to the subject's capacity for participating on an interactive sequence of speech acts which aims the communicative interchange (Mayor, 1991).

\section{Communicative Functions}

Several authors analyzed the language development through the functional perspectives and proposed taxonomies to the study of the acquisition of communicative functions. Hallyday (1975) is one of the classic authors of these studies. From a functiona perspective he described six types of communicative functions of the pre-linguistic period, between 9 and 18 months:

1. Instrumental function: the child uses language to satisfy material needs.

2. Regulatory function: the child uses language to control the other's behavior.

3. Interactive function: the child uses language to interact with others.

4. Personal function: the child uses language to express personal feelings related to other people or to the environment.

5. Heuristic function: the child uses language as an instrument to explore the environment aiming the identification of actions' and objects' names.

6. Imaginative function: the child plays with language, creating or re-creating the environment according to his/her imagination.
According to Haliday (1975) between 18 and 24 months a seventh function appears:

7. Informative function: the child uses language to convey an information. It is considered a sophisticated function because it involves the internalization of complex linguistic concepts.

Bates et al. (1976) determined two types of communicative functions: proto-declarative and proto-imperative. The proto-declaratives were defined as child's attitudes aimed to drive the adult's attention to some world's object or event of his/her interest or to obtain the adult's attention to his/herself. On the other hand the proto-imperatives are attitudes aiming that the adult perform something that the child wants, as grabbing something or producing an action. These attitudes or behaviors are characterized, for example, by movements of opening and closing the hands while trying to reach an object and looking back at the adult.

\section{Conversational abilities}

Pre-verbal communication is the precursor of conversational abilities since the communicative exchanges in which children engage provide the conversational model (Zorzi and Hage, 2004).

The ability for dialogue involves an interactive sequence of speech acts and is the result of the communicative exchange among two or more interlocutors included on a larger social context (Mayor, 1991). Besides this sequence the efficient dialogue demands from the interlocutors the compliance with turn taking rules, adherence to the topic and abilities to adapt to participants and situations. In respect to the proficiency on conversational rules the child needs to learn the roles of speaker and listener, taking his/her turns when necessary and allowing the interlocutors to take theirs (Zorzi and Hage, 2004).

The studies about conversational abilities are more restrict than the ones about communicative functions. Those which focus on the conversational development have addressed three aspects, according to Acosta et al. (2003): how the child learns the roles of speaker and listener, how he/she develops the ability to maintain the conversational topic and how he/she becomes apt to adapt to the context, that is, to the listener and to the communicative situation of which he/she is participating. 
Based on the interest about functional aspects of language researches have been addressed to provide parameters about the development of pragmatic abilities.

Klekan-Aker and Swank (1988) conducted a study about the use of language functions of 240 children between 2 and 5 years in a structured situation. Results show that the use of language functions by the studied children increasingly improved with age. Nevertheless they observed that some of these functions are completed before the others and that all of them are present before age 3:6.

Wetherby and Rodriguez (1992) conducted a study where 15 normal children in different phases of the linguistic development (pre-linguistic, language acquisition and multi-word period) were examined in structures and non-structured contexts. Results show that a significant number of questions and comments improved greatly from the linguistic to the multi-word period in both contexts. Significantly more questions were used in the structured context but there was no significant difference on the use of comments on both contexts.

Rigolet (1998) stated that 3 year-old children answer more than they ask and they are more able affirming or denying than formulation doubts. This way she proposes stimulating encouraging children to intervene by asking. The author also stressed that despite there are still some articulation failures at this age the individual differences becomes more marked: some children already are clearly more intelligible than others in their phonetic/phonological expression.

Zorzi and Hage (2004) presented tables with the pragmatic development. With 2 years children use language to request, inform, ask and interact. In the conversational perspective they start and maintain dialogues but not for too many turns. They talk to people in known contexts, about concrete issues and present referents. With 3 to 4 years they improve and intensify the use of the functions described above, asking questions about absent referents. Turns are intelligible and coherent to the prior one. With 5 and 6 years the linguistic resources to different language functions becomes increasingly sophisticated. They show metalinguistic abilities. Initiate and maintain conversation through several turns. Talk with more than one interlocutor at the same time about absent and abstract referents. Become increasingly able to correct them, when perceive that they are not being understood, rephrasing the utterance.
Cervone and Fernandes (2005) analyzed the communicative profile of 40 normal children between 4 and 5 years interacting with adults and noted that children of this age occupied the larger part of the communicative space, not limiting themselves to answering questions. The profile showed that the prevailing communicative mean was the verbal and the most common communicative functions were interactive (comment and information request).

The interest about the study of the development of pragmatic abilities in children is due, partly to the clinical context. Several studies have investigated the pragmatic abilities of children with hearing impairment, psychiatric disorders and specific language impairment (Bosa, 2002; Chiari et al., 2002; Mecca et al., 2002; Fernandes et al, 2002; Hage et al., 2002, 2006; Alves et al., 2004; Befi-Lopes et al., 2004, 2005; Souza-Morato and Fernandes, 2006).

Many children are referred to language assessment with communication complaints that are not related to articulation, vocabulary, morphology or syntax, but to conversation. Their parents state that they speak but seam not to pay attention to the other's speech because they frequently produce incoherent answers or else, seam not to clearly express their communicative intentions or show very little interest in conversation. So, how is the profile of pragmatic abilities of small children? When the inabilities on the functional use of language and conversation of a pre-school child can be considered the sign of a language disorder?

Can socio-cultural aspects interfere in these abilities? Studies suggest that cultures interfere on the refined path of development of the conversational pragmatic abilities in children (Aukurst, 2004; Villiers, 2004). Ramos et al (2002) compared the behavioral development of children of public and private day-care centers on the second years of life and found that children of the public day-care center presented a smaller proportion of behaviors in the area of language production and reception. Padovani et.al (2004), in a study about grammatical comprehension of children form different socio-cultural environments showed that children form low-income neighborhoods of Salvador (BA) presented lower levels of grammatical comprehension when compared with children from a high-income neighborhood.

In this context, this study aimed to analyze the profile of pragmatic abilities of small normal children 
and also to verify if there are significant differences in these abilities, considering the children's socialeconomic level.

\section{Method}

Subjects were 33 children between 36 and 47 months from public and private schools where the socio-economic level of the population was respectively low and medium-high. The responsible adults were informed about the study by an informative letter. Participated in this study, the children whose parents signed the consent form. This research was approved by the Research and Ethics Committee of the institution (\# 29/2003).

Of the 33 children, three were excluded form the sample because they presented a history of language delay or some motor, linguistic or interactive impairment. The exclusion of the children from the sample was based on the interviews about their development conducted by the researchers with one of the care takers (parents, teachers or educators) and also on the observation during the initial interaction with the researcher. The excluded children were referred to the language diagnostic clinic of the institution where they received the appropriate service. This way, 30 children with typical language development participated in this study, 15 from public school (9 girls, 6 boys) and 15 from private school (7 girls, 8 boys).

Prior to gathering the individual language sample of each sample, the researchers made contact with the children to establish some familiarity with them. Each selected child was taken to a room with toys (miniatures of vehicles, household items and dolls), pictures, paper, color pencils and books over a child-size table; videocamera Panasonic M 9000 fixed on a Welbon BF60 tripod, with a Dylan 201VHF microphone.

Samples of 30 minutes of semi-structured interaction between the child and the researcher were filmed in VHS tapes. The toys and pictures were used to stimulate the conversation. The researcher prompted questions or comments about the presented material (for example, the name of the animals and actions presented on the books' pictures) and provided space to the expansion of the issues on free conversation.

After recording the tapes were viewed on TV/ video equipment and the 20 final minutes, of the total 30 minutes filmed, were transcribed. Over the printed transcription of the conversation, where the child's and adult's turns were registered, the
Protocol of Evaluation of Pragmatic Abilities (annex 1) was applied. This protocol's criteria were theoretically based on the works by Halliday (1975); Bates et al. (1976), Prutting (1982) and Mayor (1991). The following points were noted:

1. Total verb turns: turns filled by speech.

2. Total non-verb turns: turns filled by gestures as affirmative or negative head movements, pointing and representative gestures.

3. Total unintelligible turns: turns impossible to transcribe due to child's unintelligible speech.

4. Total turns: adding verbal, non-verbal and unintelligible turns.

The conversational abilities noted were:

1. Number of times the child initiated conversational turns.

2. Number of times of turns the child responded and/or maintained conversational topic.

3. Number of times of turns the child didn't respond and/or maintained the conversational topic.

4. Number of times the child used simple turns: one phrase turns with just enough information to avoid interrupting conversation ("What is she doing? She is sleeping").

5. Number of times the child used expanded turns: turns with more than one phrase and with more the minimum information ("What is it? It is a little pillow. She is putting her little head on it").

6. Number of times the child initiated or responded to conversation with coherent turns: when the child's turn was coherent with the prior question, comment or request by the adult ("Are you putting her to sleep? Yes").

7. Number of times the child initiated or responded to conversation with coherent turns: when the child's turn was incoherent with the prior question, comment or request by the adult ("Are you putting her to sleep? Her pajamas are red").

The communicative functions noted were:

1. Instrumental function: number of times the child requested an object ("Give me the doll") or actions ("Open the box").

2. Heuristic function: number of times the child requested an information ("Where is the boll?, Do you want to play with it?, What is the name of this?") or permission ("Can I get it?").

3. Labeling function: number of times the child spontaneously labeled objects, persons or attributes ("This is the dog"). 
4. Informative function: number of times the child explained ("It only fits large dolls"), informed ("I will put him to sleep") or commented ("This is just like my mother's").

5. Narrative function: number of times the child used a turn to make a narrative ("She...Look, look. The bad stepmother...called the hunter to kill the Snow White").

6. Protest function: number of times the child interrupted some undesired event with speech or action ("Stop..").

7. Interactive function: number of times the child used social expressions to initiate ("hi", "hello", "how are you?") or terminate an interaction ("by", "let's go").

It is important to note that the turns could be multifunctional, that is, they could have more than one function. The characterization of communicative functions and conversational abilities was performed by three judges (at least three of the four researchers) when there was any doubt on the analysis or when more than one interpretation was possible.

The statistical analysis used the Goodman test and the non-parametric Mann-Whitney test, with significance level of 0,05 .

\section{Results}

The table 1 presents the mean, the interquartiles semi-amplitude and the minimum and maximum values of frequency of conversational abilities with the respective statistical result of each institution.

As can be observed in the table above, very few variables of the conversational abilities item presented statistic difference between the public and private institutions. They were: number of verbal turns, of simple turns and of expanded turns. The larger number of occurrences occurred in the language samples of the children from private institution.

There was an important difference between turns initiated by the children and the turns responded/ maintained by them. They used most of their turns to respond or maintain the conversation. Generally they initiated, responded or maintained conversation with simple turns, that is, they didn't expand their turns complementing them with more information. On the other side very few of the subjects assessed presented incoherent turns. There was a change of conversational topic according to their focus of interest but they seemed to be substantially coherent in their participations in dialogues.

In respect to the communicative functions there was a larger amount of use of the informative/ comment function than any other. It was observed either in children from the public institution as in the ones from private institution, with no statistically significant differences on the number of occurrences in each institution. Only the use of the narrative function produced statistical difference. The frequency of use of these and other communicative functions can be observed in the Table 2 that follows bellow. 
TABLE 1. Mean, inter-quartiles semi-amplitude, minimum and maximum values of frequence of conversational abilities with respective statistical result of each institution.

\begin{tabular}{|c|c|c|c|}
\hline \multirow{2}{*}{ Variable } & \multicolumn{2}{|c|}{ Institution } & \multirow[t]{2}{*}{ Statistical result } \\
\hline & Public & Private & \\
\hline \multirow{2}{*}{ Age (months) } & $40.0 \pm 3 . .5^{*}$ & $41.0 \pm 3.5^{*}$ & \multirow{2}{*}{$0.75(\mathrm{P}>0.05)$} \\
\hline & $(36.0 ; 47.0)$ & $(36.0 ; 47.0)$ & \\
\hline \multirow{2}{*}{ Verbal Turns } & $95.0 \pm 36.5^{*}$ & $142.0 \pm 29.5^{*}$ & \multirow{2}{*}{$2.34(\mathrm{P}<0.05)$} \\
\hline & $(27.0 ; 160.0)$ & $(70.0 ; 215.0)$ & \\
\hline \multirow{2}{*}{ Non Verbal Turns } & $38.0 \pm 31.5^{*}$ & $50.0 \pm 20.5^{*}$ & \multirow{2}{*}{$0.66(\mathrm{P}>0.05)$} \\
\hline & $(6.0 ; 164.0)$ & $(6.0 ; 75.0)$ & \\
\hline \multirow{2}{*}{ Unintelligible Turns } & $2.0 \pm 1.0^{*}$ & $1.0 \pm 1.5^{*}$ & \multirow{2}{*}{$0.76(\mathrm{P}>0.05)$} \\
\hline & $(1.0 ; 6.0)$ & $(1.0 ; 6.0)$ & \\
\hline \multirow{2}{*}{ Total of turns } & $168.0 \pm 34.5^{*}$ & $184.0 \pm 17.0^{*}$ & \multirow{2}{*}{$1.56(\mathrm{P}>0.05)$} \\
\hline & $(106.0 ; 238.0)$ & $(147.0 ; 233.0)$ & \\
\hline \multirow{2}{*}{ Initiate turns } & $18.0 \pm 14.5^{*}$ & $22.0 \pm 8.0^{*}$ & \multirow{2}{*}{$0.87(\mathrm{P}>0.05)$} \\
\hline & $(1.0 ; 70.0)$ & $(3.0 ; 79.0)$ & \\
\hline Respond or & $142.0 \pm 28.0 *$ & $153.0 \pm 8.0^{*}$ & \multirow{2}{*}{$1.68(\mathrm{P}>0.05)$} \\
\hline Maintain turns & $(69.0 ; 230.0)$ & $(137.0 ; 179.0)$ & \\
\hline \multirow[b]{2}{*}{ Doesn't respond/maintain } & $10.0 \pm 18.5^{*}$ & $7.0 \pm 7.5^{*}$ & \multirow{2}{*}{$1.41(\mathrm{P}>0.05)$} \\
\hline & $(2.0 ; 56.0)$ & $(2.0 ; 23.0)$ & \\
\hline \multirow{2}{*}{ Simple Turns } & $89.0 \pm 24.0^{*}$ & $119.0 \pm 17.5^{*}$ & \multirow{2}{*}{$2.26(\mathrm{P}<0.05)$} \\
\hline & $(27.0 ; 140.0)$ & $(66.0 ; 157.0)$ & \\
\hline \multirow{2}{*}{ Expansive Turns } & $8.0 \pm 5.0^{*}$ & $12.0 \pm 10.0^{*}$ & \multirow{2}{*}{$2.06(\mathrm{P}<0.05)$} \\
\hline & $(1.0 ; 41.0)$ & $(3.0 ; 83.0)$ & \\
\hline \multirow[t]{2}{*}{ Coherent Turns } & $166.0 \pm 31.5^{*}$ & $180.0 \pm 16.0^{*}$ & \multirow[t]{2}{*}{$1.70(\mathrm{P}>0.05)$} \\
\hline & $(99.0 ; 235.0)$ & $(145.0 ; 255.0)$ & \\
\hline \multirow[t]{2}{*}{ Incoherent Turns } & $4.0 \pm 2.5^{*}$ & $1.0 \pm 3.0^{*}$ & \multirow[t]{2}{*}{$0.91(\mathrm{P}>0.05)$} \\
\hline & $(1.0: 15.0)$ & $(1.0 ; 9.0)$ & \\
\hline
\end{tabular}

Legend: * mean \pm inter-quartiles semi-amplitude (minimum value; maximum value) 
TABLE 2. Mean, inter-quartile semi-amplitude, minimum and maximum values of the frequency of communicative functions with the respective statistical result of each institution.

\begin{tabular}{|c|c|c|c|}
\hline \multirow{2}{*}{ Variable } & \multicolumn{2}{|c|}{ Institution } & \multirow{2}{*}{ Statistical result } \\
\hline & Public & Private & \\
\hline Instrumental & $\begin{array}{l}1.0 \pm 1.5^{*} \\
(1.0 ; 10.0)\end{array}$ & $\begin{array}{l}3.0 \pm 3.5^{*} \\
(1.0 ; 14.0)\end{array}$ & $1.42(\mathrm{P}>0.05)$ \\
\hline Heuristic (question) & $\begin{array}{l}7.0 \pm 6.5^{*} \\
(1.0 ; 30.0)\end{array}$ & $\begin{array}{l}13.0 \pm 6.0 * \\
(3.0 ; 30.0)\end{array}$ & $1.44(\mathrm{P}>0.05)$ \\
\hline Labeling & $\begin{array}{l}3.0 \pm 2.5^{*} \\
(1.0 ; 26.0)\end{array}$ & $\begin{array}{l}4.0 \pm 1.5^{*} \\
(1.0 ; 23.0)\end{array}$ & $0.57(\mathrm{P}>0.05)$ \\
\hline Informative & $\begin{array}{c}135.0 \pm 29.5^{*} \\
(82.0 ; 223.0)\end{array}$ & $\begin{array}{l}146.0 \pm 17.5^{*} \\
(128.0 ; 185.0)\end{array}$ & $1.25(\mathrm{P}>0.05)$ \\
\hline Narrative & $\begin{array}{l}1.0 \pm 0.5^{*} \\
(1.0 ; 6.0)\end{array}$ & $\begin{array}{l}2, .0 \pm 1.5^{*} \\
(1.0 ; 11.0)\end{array}$ & $1.96(\mathrm{P}<0.05)$ \\
\hline Protest & $\begin{array}{l}1.0 \pm 0.0^{*} \\
(1.0 ; 3.0)\end{array}$ & $\begin{array}{l}1.0 \pm 1.0^{*} \\
(1.0 ; 7.0)\end{array}$ & $1.46(\mathrm{P}>0.05)$ \\
\hline Interactive & $\begin{array}{l}1.0 \pm 0.5^{*} \\
(1.0 ; 11.0)\end{array}$ & $\begin{array}{c}1.0 \pm 0.5^{*} \\
(1.0 ; 6.0)\end{array}$ & $0.21(\mathrm{P}>0.05)$ \\
\hline
\end{tabular}

Legend: * mean \pm inter-quartiles semi-amplitude (minimum value; maximum value)

\section{Discussion}

Aiming to analyze the profile of pragmatic abilities of normal children and also to determine if there were significant differences in these abilities considering the social-economic level of the children, this study assessed 30 children with three years of age.

Considering the language sample of the 30 children it was found a minimum total number of 106 turns in a 20 minutes sample what, according to Acosta et al. (2003) allows a satisfactory assessment of conversational abilities and communicative functions in a spontaneous language sample. But we emphasize that this was the minimum number of turns observed; the maximum value was 238 turns. These two values were found in children from the public institution; the minimum and maximum values in the private institution were 147 and 233, respectively. It is important to note that there was no statistically significant difference between the means of total turns observed, with values of 168 and 184, respectively, to children from public and private institutions.

Unintelligible turns had low occurrence. This finding agrees with the ones reported by Rigolet (1998), who stated that despite there are still some articulatory inabilities in this age, the children are already more clear in their phonetic/phonological expression. The phonological simplification that most impair the speech intelligibility, as reduplication, occlusive's anteriorization and oclusivation already disappeared at this age (Wertzner, 2004).

In some moments the children used non-verbal means of expression when taking their turns, as head affirmative or negative movements, gestures as response to researcher's demands, questions or comments or to drive attention to something in the room. The maximum and minimum values of occurrence in each institution and the means are presented in Table 1, without statistical significant difference between public and private institutions. Non verbal means were frequently used by the children of this study. It is important to note that non-verbal communication never disappears and is a frequent language mean also of the adult, who has all the linguistic resources to communicate verbally.

The normal children of this study presented coherent turns in most of the interaction time. There was change of conversation topic by the children according to their focus of interest but they appeared to be coherent in their participations in the dialogue. It seems to us that this is a finding that may serve as a parameter when assessing turns of children with language disorders. 
In Table 1 it can also be observed the low mean of the variable "non-response" and the absence of statistical difference between both institutions despite the maximum number of non-response have been relatively high when compared to the minimum number of total turns.

It was also observed that during conversation all children, independently of institution responded or maintained turns much more than they initiated. This data might have been influenced by the semistructures interaction in which the adult constantly formulated questions about the toys and pictures presented. On the other side, Rigolet (1998) stated that 3 year old children preferred to agree or disagree instead of formulating doubts, that is, they respond more than they initiate conversation.

In what refers to turn expansion, the children produced more simple turns than expanded ones. This variable had statistical difference between the children from private and public institutions. There was also a statistically significant difference on the productions of verbal turns, simple or expanded. Children from private school produced a larger number of verbal turns, either simple or expanded.

At least in this analyzed sample the social environment influence seems to exist, specifically the educational environment. During the visit to the schools to the recording of the filmed samples differences on the ways of conducting activities and also of physical aspects were observed. While in the public school there were a great number of children in each classroom and lack of resources as computers and infantile libraries, in the private school there were all these resources and a small number of children in each classroom, facilitating more interactivity between teachers and children. In private school conversation was encouraged. The children were constantly encouraged to tell histories, talk about small events, comment and explain. These strategies promote turns with more linguistic resources. The same wasn't observed in the public school: the children played with toys and rarely were asked to tell, comment or explain.

Studies suggest that culture influences the refined path toward the development of conversational abilities in children (Aukrust, 2004; Villiers, 2004). Language development presents universal aspects that can be identified regardless of the social cultural environment, as well as individual aspects, which are influenced by the language spoken in the immediate environment. Some general characteristics are shared by all individual of the species regarding linguistic evolution, however, some characteristics are dependent on the environment in which the subject lives and his/her personal, family, social-economic or educational characteristics. This way, socialcultural variables can justify some conversational and functional aspects of the spoken language.

In Table 2, referring to the communicative functions, it can be observed that most of the children's production had informative function. The material used to the interaction (books, pictures, miniatures and drawings) leaded to interactive situations with many questions and answers and the free conversation allowed comments. This fact may have contributed to this function's more frequent performance. But this profile of difference between this function and all the others characterized all the children assessed even when considering that the interaction varied in each case (some children were more involved in drawing, others or more interested in books and pictures and others spoke more spontaneously).

The other functions, although less frequent were used at least once by all children (see Table 2). Klekan-Aker and Swank (1988) observed that some functions are acquired before the others, but that all are present before 3.6 years.

Only the narrative function presented statistically significant difference between public and private institutions, with more number of turns of children of the private school. Here we are drawn back to the discussion of the social-interactive environment observed in public and private schools it was observed that the use of narrative is frequently stimulated in the firt ones. According to Fontes and Cardoso-Martins, interactive history reading programs may have a positive impact in narrative abilities on oral language development. This way, the strategy used by the private institution to stimulate narratives is a socialinteractive variable that may justify the greater occurrence of the narrative function in the turns of the children of this institution.

\section{Conclusion}

Based on the language samples of the 30 children assessed it was possible to conclude that when dialoguing with 3 years old children, they respond more than they iniciate conversation and rarely fail to respond to the interlocutor. In their production they use predominantly simple and coherent turns. Conversation is maintained through verbal and non-verbal turns, with the verbal one prevailing. Conversation was not impaired by unintelligible turns. 
Analyzing the occurrence of communicative functions the informative prevailed, but all the others (instrumental, heuristic, labeling, narrative, protest and interactive) were used by the assessed children.

Comparing the performance of children from private and public institutions statistically significant differences were observed on the criteria of verbal turns (simple or expansive) and narrative function, with the larger occurrence of turns with these characteristics by the children from private school. Supported by the socio-linguistic studies these findings were not considered a communication delay of children of low socialeconomic level, but a variation of social-cultural nature.

Studies about the pragmatic profile of groups of normal children of different social-economic levels may bring important contributions not only to determine general parameters through which assess children with language disorders but also to identify differences that are not deviations but linguistic variation due to social interaction.

\section{Apendix}

Evaluation of pragmatic abilities protocol

Name:

Date of birth:

Eschool/grade:

Date:

Researcher:

Total of verbal turns:

Total of non-verbal turns:

Total of unintelligible turns:

Total of turns (verbal, non verbal, unintelligible

(Obtain a video language sample of 30 minutes in free conversation situation. Proceed to the analysis of the last 20 minutes)

Analysis criteria

1 - conversational abilities - number of occurrences:

1.01 - initiate conversational turns:

1.02 - respond/maintain conversational turns:

1.03 - don't respond/maintain:

1.04 - simple turns:

1.05 - expansive turns:

1.06 - coherent turns:

1.07 - incoherent turns:

2 - communicative functions - number of occurrences:

2.01 - Instrumental: demands (asks) object and actions:

2.02 - Heuristic: demands information (asks):

2.03 - Labeling:

2.04 - Informative: informs, explains or comments:

2.05 - Narrative:

2.06 - Protest: protests or stops an undesired event:

2.07 - Interactive: use of social expressions to initiate or terminate interaction:

Researcher's observations: 


\section{References}

ACOSTA, V. M.; MORENO, A.; RAMOS, V.; QUINTANA, A.; ESPINO, O. Avaliação do desenvolvimento pragmático. In: ACOSTA, V. M. (Org.). Avaliação da Linguagem: teoria e prática do processo de avaliação do comportamento lingüístico-infantil. São Paulo: Santos, 2003. p. 33-51.

ALVES, T. E.; FRANCO, K. E. V. B.; HAGE, S. R. V. Habilidades conversacionais de crianças gêmeas: influência da encefalopatia bilirrubínica. R. Cefac, São Paulo, v. 6, n. 3, p. 253-258, jul.-set. 2004.

AUKRUST, V. G. Talk about with young children: pragmatic socialization in two communities in Norway and the US. $J$. Child Lang., New York, v. 31, n. 1, p. 177-201, feb. 2004.

BATES, E.; CAMAIOni, L.; VOlTerRA, V. The acquisition of performatives prior to speech. In: BATES, E. (Org.). Language and context. Nova Iorque: Academic Press, 1976. p. 111-128.

BEFI-LOPES, D. M.; RODRIGUES, A.; ROCHA, L. C. Habilidades lingüístico-pragmáticas em crianças normais e com alterações de desenvolvimento de linguagem. PróFono R. Atual. Cient., Barueri (SP), v. 16, n. 1, p. 57-66, jan.-abr. 2004.

BEFI-LOPES, D. M.; ARAÚJO, K.; GIUSTI, E. Relação entre as habilidades fonológicas e pragmáticas nos distúrbios específicos de linguagem. Pró-Fono R. Atual. Cient., Barueri (SP), v. 17, n. 1, p. 45-54, jan.-abr. 2005.

BOSA, C. Atenção compartilhada e identificação precoce do autismo. Psic. Refl. Crít., Portp Alegre, v. 15, n. 1, p. 77-88, jan.-abr. 2002.

CERVONE, L. M.; FERnANDES, F. D. M. Análise do perfil comunicativo de crianças de 4 e 5 anos na interação com o adulto. R. Soc. Bras. Fonoaudiol., São Paulo, v. 10, n. 2, p. 97-105, abr.-jun. 2005.

CHIARI, B. M.; BRAGATTO, E. L.; BARBOSA, T.; STROBILIUS, R.; SOARES, T. C. B. Avaliação da intencionalidade e funcionalidade da comunicação em crianças deficientes auditivas e ouvintes entre 24 e 60 meses. Pró-Fono R. Atual. Cient., Barueri (SP), v. 14, n. 2, p. 187-198, maio-ago. 2002.

FERNANDES, F. D. M.; VIDAL, A. F.; SILVA, D. F. B.; MANGILLI, L. Perfil da pragmática de sujeitos com quadros psiquiátricos na primeira avaliação fonoaudiológica. R. Soc. Bras. Fonoaudiol., São Paulo, v. 7, n. 1, p. 38-43, jun. 2002.

FONTES, M. J. O.; CARDOSO-MARTINS, C. Efeitos da leitura de histórias no desenvolvimento da linguagem de crianças de nível sócio-econômico baixo. Psic. Refl. Crít., Porto Alegre, v. 17, n. 1, p. 83-94, jan.-abr. 2004.

HALLIDAY, M. K. Learning how to mean. Londres: Eward Arnold, 1975.

HAGE, S. R. V.; SILVEIRA, D. N.; GARBINO, J. F. O diagnóstico clínico do distúrbio léxico-sintático. Pró-Fono R. Atual. Cient., Barueri (SP), v. 14, n. 3, p. 409-414, set.-dez. 2002.
HAGE, S. R. V.; CENDES, F.; MONTENEGRO, M. A.; ABRAMIDES, D. V. M.; GUIMARÃES, C. A.; GUERREIRO, M. M. Specific language impairment: linguistic and neurobiological aspects. Arq. Neuro-Psiquiat., São Paulo, v. 64, n. 2A, p. 173-180, jun. 2006.

KLECAN-AKER, J. S.; SWANK, P. R. The use of a pragmatic protocol with normal preschool children. $J$. Commun. Dis., New York, v. 21, n. 1, p. 85-102, feb. 1988.

MAYOR, A. La pragmática del lenguaje: consideraciones para la intervención. Leng. Comun., Madri, v. 7, p. 1721, 1991.

MECCA, F. F. D. N.; CÁRNIO, M. S.; LICHTIG, I. Perfil das funções de linguagem em crianças surdas na idade de 3 a 7 anos. Pró-Fono R. Atual. Cient., Barueri (SP), v. 14 n. 3, p. 449-458, set.-dez. 2002.

PADOVANI, C. M. C. A.; COSTA, E. A.; SILVA, L. A. Efeito do contexto sociocultural na compreensão da linguagem oral. R. Soc. Bras. Fonoaudiol., São Paulo, v. 9, n. 3, p. 151-155, jul.-set. 2004.

PRUTTING, C. A. Pragmatics as social competence. $J$. Speech Hear. Dis., Rockville, v. 47, n. 2, p. 123-134, may 1982.

RAMOS, C. S.; PEDROMÔNICO, M. R. M.; SHINZATO, A. R.; DE LUCCAS, S. Comparação do desenvolvimento do comportamento de crianças de creches públicas e particulares no segundo ano de vida. Pró-Fono R. Atual. Cient., Barueri (SP), v. 14, n. 3, p. 401-408, set.-dez. 2002.

RIGOLET, S. A. N. Para uma aquisição precoce e optimizada da linguagem: linhas de orientação para crianças até os seis anos. Porto (Portugal): Porto, 1998.

SOUZA-MORATO, P. F.; FERNANDES, F. D. M. Análise do perfil comunicativo quanto à adaptação sóciocomunicativa em crianças do espectro autístico. $R$. Soc. Bras. Fonoaudiol., São Paulo, v. 11, n. 2, p. 70-74, abr.jun. 2006.

VILLIERS, P. Assessing pragmatic skills in elicited production. Semin. Speech Lang., New York, v. 25, n. 1, p. $57-71$, feb. 2004.

WERTZNER, H. F. Prova de fonologia. In: ANDRADE, C. R. F.; BEFI-LOPES, D. M.; FERNANDES, F. D. M.; WERTZNER, H. F. ABFW: teste de linguagem infantil nas áreas de fonologia, vocabulário, fluência e pragmática. 2 . ed. Carapicuíba (SP): Pró-Fono, 2004.

WETHERBY, A. M.; RORIGUEZ, G. P. Measurement of communicative intentions in normally developing children during structured and unstructured contexts. J. Speech Hear. Res., Rockville, v. 35, p. 130-138, feb. 1992.

ZORZI, J. L.; HAGE, S. R. V. Protocolo de observação comportamental: avaliação de linguagem e aspectos cognitivos infantis. São José dos Campos (SP): pulso editorial, 2004 